\title{
Aneusomaty in the Leaves of Diploid Petunia
}

\author{
by Shin TAKEHISA*
}

Received August 18, 1961

Duncan $\left.\left(1945^{1}\right)\right)$ reported that the somatic chromosome number within root-tips of Paphiopedilum Wardii fluctuates from cell to cell around the diploid number, and proposed the term "aneusomaty" for this phenomenon. This phenomenon, on the other hand, has been termed "chromosome mosaic" by Fankhauser (1945")). The occurrence of variable chromosome numbers in somatic tissue within individual plants has been reported in a number of plant families (Snoad, 1955'), Hegwood and Hough $\left.1958^{4}\right)$, Kato $\left.1960^{5}\right)$ ). In Petunia, Levan $\left(1937^{6}\right)$ ) observed the indication of aneusomaty in his $\mathrm{F}_{2}$ individuals derived from diploid-tetraploid cross, but he did not pay any particular attention to it.

Table 1. Chromosome class distribution in the aneusomaty individual of diploid Petunia hybrida.

\begin{tabular}{|c|c|c|c|c|c|c|c|c|c|c|c|}
\hline \multirow{2}{*}{$\underset{\text { (preparation) }}{\text { Leaf }}$} & \multicolumn{10}{|c|}{ Chromosome class } & \multirow{2}{*}{$\mid \begin{array}{c}\text { Total number } \\
\text { of } \\
\text { observed cells }\end{array}$} \\
\hline & $14(2 n)$ & 16 & $21(3 n)$ & 22 & 23 & 24 & 25 & 26 & 27 & $28(4 n)$ & \\
\hline A & 19 & 1 & 2 & 1 & 5 & 5 & 1 & 4 & 1 & 1 & 40 \\
\hline B & 9 & & 1 & 1 & 2 & 2 & 4 & 1 & & & 20 \\
\hline $\mathrm{C}$ & 7 & & & & & & & & & & 7 \\
\hline $\mathrm{D}$ & 8 & & & & & & & & & & 8 \\
\hline
\end{tabular}

Examining the somatic chromosomes of Petunia by the leaf smear technique with the Feulgen stain (Sullivan, 1947 $)$ ) the author found the aneusomaty in an individual within diploid $(2 n=14)$ plants of Petunia hybrida, commercial name "Snow Ball" (Table 1 and Figures). A series of examination was undertaken on different young leaves taken from several stems of the plant. As shown in Table 1, about half of observed cells in the leaf $\mathrm{A}$ and $\mathrm{B}$ had increased chromosome numbers ranging from triploid to tetraploid number. The leaf $\mathrm{C}$ and $\mathrm{D}$ did not show any change of chromosome number so far as the present examination is concerned. This result indicates that the phenomenon of aneusomaty in this plant has not taken place in every leaf. There was morphologically no difference between the aneusomaty individual and the plants with normal chromosome number.

Many reports on the occurrence of aneusomaty in a number of plant families have indicated that the aneusomatic condition is apparently due to mitotic abnormalities such as split spindle, kinetochore pairing in somatic cells, and somatic bridges

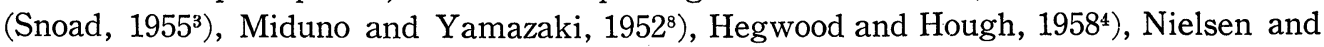
Nath, $\left.1961^{9}\right)$ ). Further, the aneusomaty found in wheat (Love, 1938 $\left.{ }^{10}\right)$ ), Hymenocallis calathinum (Snoad, 19553)), apple (Hegwood and Hough, 1958)), and Agroelymus (Nielsen and Nath, 1961 $)$ ) suggests that the potentiality to produce aneusomaty is

\footnotetext{
* Botanical Institute, Faculty of Science, Hokkaido University, Sapporo, Japan.
} 
heritable or has relation to hybridity. The present case of aneusomaty represents the sporadical occurrence of aneusomaty in the leaves of one individual. The species Petunia hybrida has originated from interspecific hybridization since 1937 or so (Stout, 1952 $\left.{ }^{11}\right)$ ). Therefore it is considered that the present case of aneusomaty may have a background of genetical potentiality to produce aneusomaty and have a correlation to the hybrid origin of the species. However, the existence of genetical potentiality to produce aneusomaty is nothing but a remote cause of aneusomaty, and this cannot explain the manner through which these variable chromosome numbers have arisen. In connection with this point, there is a report that the mitotic abnormalities such as sticky bridges could be induced by genetical endogenous factors, i.e. the mitotically abnormal condition observed in the young leaf meristem of Ginkgo biloba $\mathrm{L}$. is due to some endogenous substances, which become effective when amounted up over a certain threshold concentration during a specified growth period (Tanaka et al., 1952 $\left.{ }^{12}\right)$ ). On the contrary, in the present case, multinucleate cells which suggest the pre-existence of split spindle and cells with subdiploid chromosome numbers probably resulting from kinetochore pairing or somatic bridges were not observed. The lack of chromosome numbers from $2 n$ to $3 n$ only with one exception, if it is true, may also suggest that a gradual stepwise increase of chromosome number is improbable. These facts suggest that other mechanisms than mitotic abnormality may be responsible for the occurrence of aneusomaty in the present case.

From the fact that the aneusomatic chromosome numbers are concentrated to the range from triploid to tetraploid, two alternative mechanisms may be assumed by which the aneusomaty in this diploid Petunia originated. The one is that the endoreduplication (Levan and Hauschka, 1953 ${ }^{13}$ )) of chromosome complement took place initially, and then the elimination of certain members of chromosomes occurred. The other is that the endoreduplication of variable number of chromosomes, not of whole chromosome complement, occurred once or sometimes at an earlier stage of development, possibly accompanied by a fluctuation of numbers through succesive mitotic divisions. The latter mechanism may include the case in which the duplication of chromosome occurs differently among constituent genomes.

Since, however, the observation of whole mitotic cycle was not attempted in the present paper, which will provide with informations giving clue to the really operative mechanisms of the aneusomaty in the present case, decisive conclus on must await further studies.

The author wishes to express his gratitude to Professor Hajime Matsuura for his suggestion and criticism during the course of this study. The gratitude is also due to Professor Tadanori Miduno, Keio University, for his kind criticism.

\section{References}

1) Duncan, R. E., Amer. J. Bot. 32: 506 (1945).

20 (1945). 3) Snoad, B., Heredity 9: 129 (1955).
2) Fankhauser, G., Quart. Rev. Biol. 20: 4) Hegwood, M. P., and Hough, L. F., Kromosomo 42-43: 1447 (1960) A., Svensk Bot. Tidskrift 31: 1 (1937). 7) Sullivan. T. D., Bull. Torrey Bot. Club 74: 453 (1947). 8) Miduno, T., and Yamazaki, N., Jap. Jour. Genet. 27: 210 (1952). 9) Nielsen, E. L., and Nath, J., Amer. J. Bot. 48: 345 (1961). 10) Love, M., Genetics 23: 517 (1938). 11) Stout, A. B., Memoirs Torrey Bot. Club $20(3)$; Reproduction in Petunia (1952). 12) Tanaka, N., Takemasa, N., and Sinoto, Y., Cytologia I7: $112(1952) . \quad 13)$ Levan, A., and Hauschka, T. S., J. Nat. Cancer Inst. 14: 1 (1953). 


\section{Explanation of Figures}

Photomicrographs of Feulgen leaf smears of diploid Petunia hybrida showing aneusomaty, ca. $\times 6000$. Fig. 1. Two adjacent cells showing tetraploid $(\mathrm{A}, 4 n=28)$ and diploid $(2 n=14)$ condition each. Figs. 2, 3. A diploid cell. Fig. 4. A cell having 27 chromosomes. Fig. 5. A cell having 26 chromosomes.

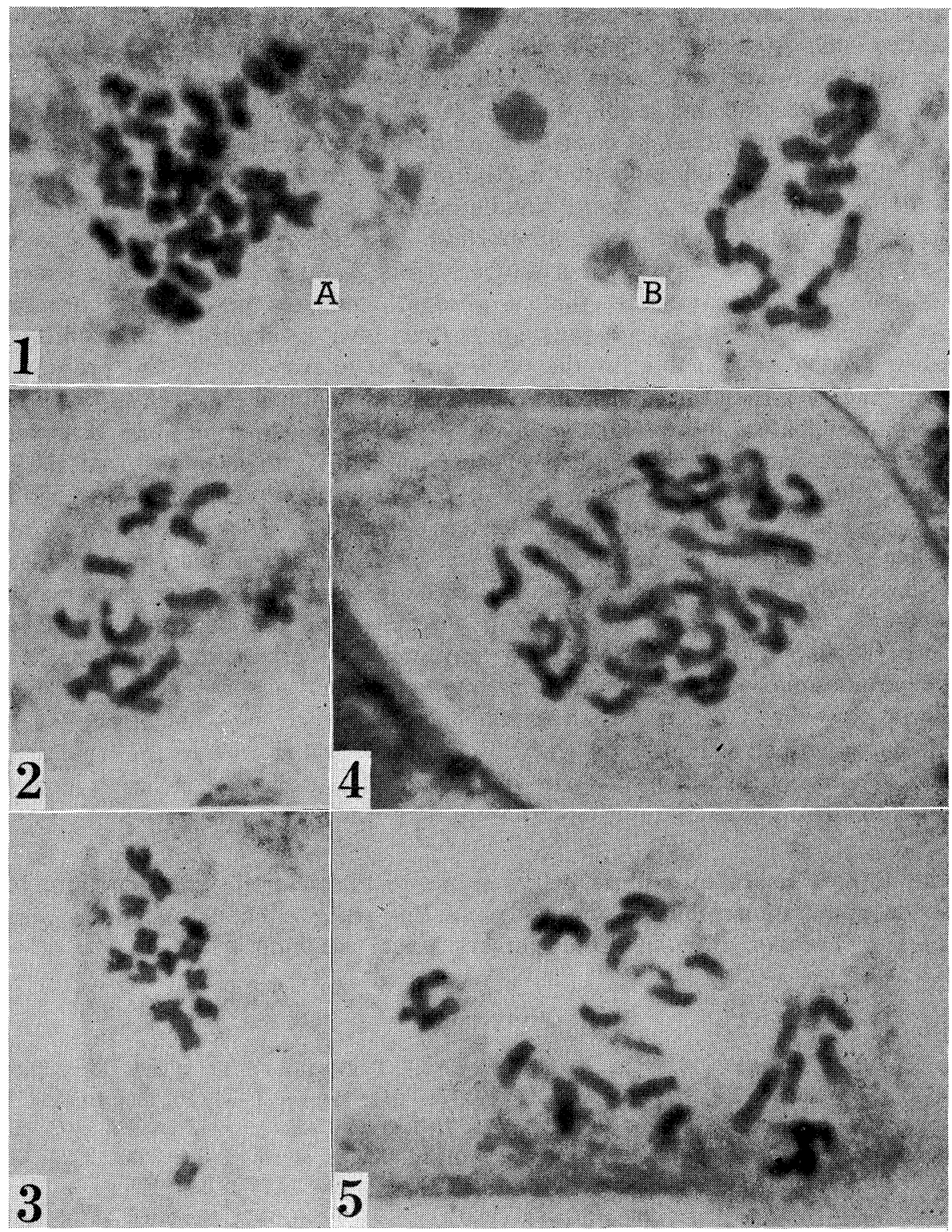




\section{摘 要}

武 久慎：二倍体ペチュニアの葉の分裂細胞における Aneusomaty

葉の分裂細胞でペチュニアの染色体を調べていた際, 偶然二倍体ペチュニア (Petunia hybrida) の園芸 品種名“Snow Ball” と呼ばれる系統のるのの中の一株が， Aneusomatyを示しているのを見出した. この現象はこの個体の総ての葉に共通して起こっているのではない. $2 n=14$ の正常な染色体数からの変 化が注とんぞ $3 n$ と $4 n$ との間にあることから, その原因と出現機構について簡単に考察した。（北海道 大学理学部植物学教室) 